\title{
Blogs - \\ Læringsfællesskab med rum til refleksion
}

\section{Dorthe Boe Danbjørg}

Adjunkt, Uddannelsesleder, Klinisk

sygeplejeforsker, ph.d.

Center for innovativ medicinsk teknologi \& Quality of Life Research Center, Hæmatologisk Afdeling, Odense Universitetshospital \& Syddansk Universitet.

\section{Jane Clemensen}

Professor, ph.d.

Center for innovativ medicinsk teknologi, Pædidatrisk Forskningsenhed, HCA Børnehospital Klinisk Institut, Det sundhedsvidenskabelige Fakultet, Syddansk Universitet \& Odense Universitetshospital.

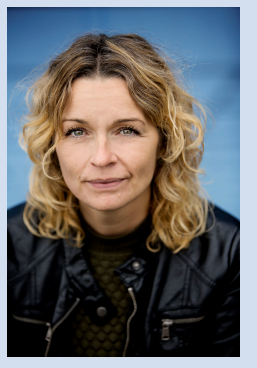

\section{Pernille Stenkil Hansen}

Elæringskonsulent

SDU Universitetspædagogik, Syddansk Universitet.
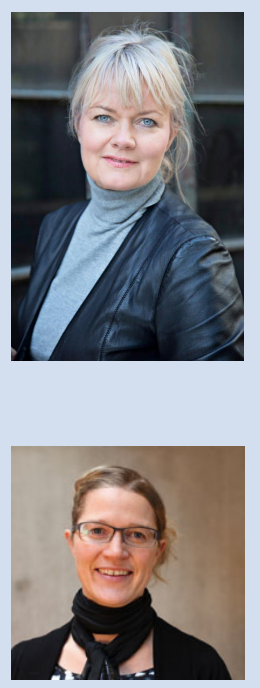


\section{Lars Thrysøe}

Ekstern lektor og Sygeplejeforsker, ph.d. Hjertemedicinsk Afdeling B, Klinisk Institut, Det Sundhedsvidenskabelige Fakultet, Odense Universitetshospital \& Syddansk Universitet.

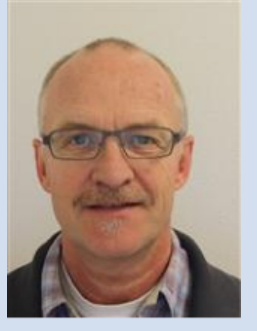

\section{Mette Juel Rothmann}

Klinisk sygeplejeforsker, adjunkt, ph.d. Center for innovativ medicinsk teknologi, Endokrinologisk Afdeling, Reumatologisk Afdeling Klinisk Institut, Det sundhedsvidenskabelige fakultet, Syddansk Universitet.

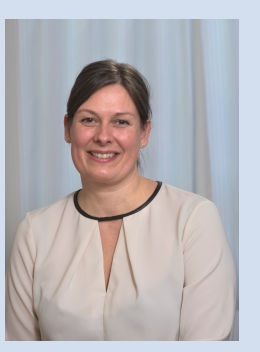

Klik her for at angive tekst.

\section{Abstract}

Anvendelse af blogs i læringssituationer kan give studerende mulighed for at reflektere i fællesskab. Derfor blev blogs afprøvet blandt universitetsstuderende med det formål at undersøge, hvordan studerende oplever anvendelsen af blogmediet, samt undersøge hvilke former for refleksion, som blogs kan understøtte. Undersøgelsen var baseret på en sociokulturel forståelse af læring, hvor læring ses som en proces, der konstrueres gennem interaktioner. Blogs blev afprøvet som en del af et undervisningsforløb for 24 studerende.

Blogindlæggene blev analyseret mhp at identificere refleksionsniveauet, og der blev gennemført et fokusgruppeinterview med fem studerende for at afdække de studerendes oplevelser med at blogge.

Konklusionen er at blogmediet tilbyder et læringsfælleskab, som giver de studerende mulighed for refleksion. Desuden tyder det på, at muligheden for refleksion forringes ved uklarhed over opgaven og usikkerhed på hvordan blogmediet anvendes. Endelig kan anvendelsen af blogs i læringssituationer udfordre de gængse opfattelser af læring, hvilket kan skabe forvirring hos de studerende. 


\section{Abstract in English}

The use of blogs in learning situations offers students the possibility to reflect collaboratively. Therefore, blogs were tested among university student s in order to investigate how students experience the use of blogs and to investigate on which levels of reflections that blogs can support. The study was based on a socio cultural understanding of learning, where learning is seen as a process that is constructed through interaction with.... Blogs were tested as a part of a course among 24 students.

The blog entries were analysed in order to identify the level of reflection, and a focus group interview with five students was conducted to explore the students' experiences with blogging.

The conclusion shows that the blog medium offers a learning community with possibility for co-reflection. Furthermore, the opportunity for reflection seems reduced when there is confusion about the assignment and insecurity how to use the blog. Finally, the use of blogs in learning situations blogs challenges the common perception of learning, which can cause confusion among the students.

\section{Introduktion}

Litteraturgennemgangen viser, at anvendelse af blogs i læringssituationer kan give de studerende mulighed for at reflektere i fællesskab (Halic, Lee, Paulus, \& Spence, 2010; Osman \& Koh, 2013; Williams \& Jacobs, 2004). Eftersom refleksion er en grundlæggende del af studerendes læringsproces, er det vigtigt at tilrettelægge undervisningsforløb, som kan stimulere studerende til at være undersøgende, nysgerrige og eftertænksomme for hermed at understøtte deres evne til refleksion (Dewey, 1933/2009).

En blog er en webside, som giver bloggeren mulighed for at 'poste' indhold. Indholdet kan være tekst, der kan suppleres med links, videoer, billeder (Farmer, Yue, \& Brooks, 2008). Det kan sammenlignes med en online dagbog, men til forskel fra den analoge dagbog, inviterer forfatteren læserne til at kommentere på indlæg (Papacharissi, 2007). Derfor er blogs at betragte som en transformational technologie (Williams \& Jacobs, 2004; Wrede, 2003), hvor teknologien i undervisningssammenhænge giver studerende mulighed for at interagere med hinanden og hermed engagere sig i hinandens arbejde og læring uafhængigt af tid og sted (Davidsen \& Ryberg, 2016; Osman \& Koh, 2013; Williams \& Jacobs, 2004).

Det interaktive og dynamiske aspekt anses som en af de centrale pædagogiske fordele ved blogs, idet det stimulerer til en supportive 
reflective practice (Osman \& Koh, 2013) hvilket kan sidestilles med et praksisfællesskab (Farmer et al., 2008).

Som nævnt viser flere internationale studier, at blogmediet fremmer refleksion hos studerende, men der mangler forskning i kvaliteten af de studerendes refleksioner, idet størstedelen af studierne bruger selvrapporterede data (Sim \& Hew, 2010). Derfor er det interessant at undersøge hvilke former for refleksion, der fremmes ved anvendelse af blog.

De studerende er ofte vant til at være online og være på de sociale medier, men de studerende kan være usikre, når de skal træde ind i rollen som online studerende (Christensen, 2016), Salmon pointerer ligeledes, at de virtuelle læringsrum er at betragte som en ny kontekst for læring for de studerende (Salmon, 2013). Derfor sætter dette studie også fokus på, hvordan de studerende oplever at anvende blogs.

Derfor undersøges følgende spørgsmål

Hvordan oplever de studerende det at blogge i forhold til at understøtte mulighed for refleksion i et læringsfællesskab?

Hvilke former for refleksion kan brugen af blogs understøtte?

\section{Teoretisk ramme}

Undersøgelsen baseres på en sociokulturel forståelse af læring, som vi finder hos Dysthe, hvor læring er en proces, der konstrueres gennem interaktion. Dysthe betragter det at skrive som forudsætning for læringsprocesser herunder refleksion. At skrive kan hjælpe den studerende til at udvikle og organisere tanker, og hermed konstruere læring (Dysthe, 2001, 2002; Ulstrup \& Haugaard Jeppesen, 2010). Rammen for undersøgelsen baserer sig på Lave og Wengers teori om praksisfællesskab (Lave \& Wenger, 2003; Wenger, 2004), teorier om refleksion af Dewey og Schön (Dewey, 1933/2009; Schön, 1991) og litteratur omkring blogmediet.

Ifølge Lave og Wenger tilegner den lærende sig faglig identitet gennem deltagelse som novice i et praksisfællesskab (Lave \& Wenger, 2003; Wenger, 2004). Et praksisfællesskab er konstitueret af gensidigt engagement, fælles virksomhed, gensidig ansvarlighed og et fælles repertoire (Wenger, 2004). I forhold til at understøtte de studerendes mulighed for refleksion og deres deltagelse i forpligtende læringsfællesskaber, er det vigtigt at etablere rum - også udenfor klasserummet - som kan stimulere de studerendes deltagelse i et praksisfællesskab. Blogging kan give de studerende mulighed for at indgå i et online fællesskab, hvor de kan engagere sig i fx gruppearbejde, opgaver og sociale aktiviteter etc. 
Begrebet refleksion er inspireret af Dewey og Schön (Dewey, 1933/2009; Schön, 1991). Dewey anses som en af de første til at definere refleksion: de studerende skal stimuleres til nysgerrighed, så de forholder sig til et givent emne på en åben måde, som gør, at de overvejer forskellige muligheder og også gennem refleksionen kan se nye sammenhænge. Dewey kalder det: "at gøre ting meningsfulde" (Dewey, 1933/2009). Altså den studerende skal bruge viden og teori til at forstå verdenen med og til at skabe mening. Dette sidestilles med den proces som de studerende gennemgår, når de søger efter viden og poster indlæg i en blog.

Dette ses også hos Schön, som primært har arbejdet med refleksion hos professionelle. Her konstitueres den reflekterende tænkning af en aktiv, vedblivende og grundig overvejelse, hvor intet bliver reduceret til rutine eller vane (Schön, 1991). Rummet til at overveje er netop det, som blogmediet kan understøtte. Osman og Koh fremhæver, at 'the collaborative affordances of blogs' kan facilitere muligheder for de studerende, hvor de kan opnå refleksion, da blogging udfordrer de studerendes vanetænkning (Osman \& Koh, 2013).

Kember har med udgangspunkt i både Dewey og Schön udviklet en syntetiseret definition af refleksion, som rummer fire niveauer af reflekterende tænkning : non refleksion, forståelse, refleksion, kritisk refleksion (Kember d., 2008). Kember har, med afsæt i de forskellige niveauer, udviklet et kodeskema for netop at kunne vurdere refleksionsniveauet i skriftligt arbejde. Skemaet er testet for gyldighed og validitet, og vurderes derfor anvendeligt (Bell, Kelton, McDonagh, Mladenovic, \& Morrison, 2011; Kember d., 2008). For udfoldelse af de enkelte niveauer se kodeskemaet i tabel 2.

Med udgangspunkt i socialkonstruktivistisk pædagogisk teori fremhæver Farmer, at blogmediet understøtter både monolog og dialog i et skriftligt online læringsmiljø. Det giver mulighed for, at bloggeren kan udtrykke sin egen refleksion (monolog), men samtidig kan engagere sig i et socialt netværk af interaktive kontakter og udveksling af synspunkter (dialog) og herigennem tilegne sig ny viden (Farmer et al., 2008). Hermed støtter blogging de studerende i at opnå høj grad af viden gennem processen med at søge og poste (skrive om det), ligesom kommentarer og respons på posts fremmer refleksion hos de studerende (Farmer et al., 2008).

Osman og Koh fremhæver, at blogs giver den studerende en stemme, og et legitimt sted at udtrykke sig, som kan øge den studerendes oplevelse af engagement og interesse i at lære (Osman \& Koh, 2013). Farmer fremhæver ligeledes, at det dermed giver de studerende en legitim mulighed for at deltage og blive indkultiveret i et praksisfællesskab (Farmer et al., 2008). Blogmediet er samtidig dynamisk, som betyder, at de studerende kan skrive, når de har tid og lyst, og deres medstuderende kan svare, når de har tid og lyst (Davidsen \& Ryberg, 2016; Osman \& Koh, 2013; 
Williams \& Jacobs, 2004) Dette kan understøtte et læringsfællesskab uafhængig af tid og sted.

\section{Design}

\section{Metodologiske overvejelser}

De studerende blev bedt om at skrive blogindlæg og kommentere på hinandens indlæg. Dernæst blev der gennemført et fokusgruppeinterview (Halkier, 2010) med henblik på at få en dybdegående og nuanceret forståelse af, hvordan de studerende oplevede at blogge.

For at kunne svare på hvilke niveauer for refleksion, som anvendelsen af blogs kan understøtte, blev blogindlæggene og kommentarerne analyseret med udgangspunkt i Kembers kodeskema (Kember d., 2008).

\section{Kontekst og intervention}

Undersøgelsen blev gennemført forår 2016 på Kandidatuddannelsen i Klinisk Sygepleje på Syddansk Universitet. De studerende var på daværende tidspunkt på andet semester af deres kandidatuddannelse. Modulet var 'Sundhedsteknologi', hvor evalueringen året før viste, at de studerende efterlyste rum til refleksion (Rothmann, Clemensen, \& Danbjørg, 2017). Derfor valgte vi at afprøve hvorvidt blogging som beskrevet indledningsvis kan stimulere til refleksion (Halic et al., 2010; Osman \& Koh, 2013; Williams \& Jacobs, 2004). De studerende arbejder med sundhedsteknologi som en del af en brugerdreven innovationsproces, hvor refleksion er væsentlig at stimulere hos de studerende.

De studerende blev stillet to opgaver. De studerende skulle i en projektgruppe (fire - fem studerende) to gange i løbet af modulet (10 uger) skrive et blogindlæg samt kommentere på deres medstuderendes blogindlæg.

Opgaverne lød således:

1) Gør jer overvejelser om anvendelsen af brugerdreven innovation.

2) Gør jer overvejelser omkring jeres ide til en sundhedsteknologi ved hjælp af teori præsenteret på undervisningen eller selvvalgt.

Introduktion af de studerende til blogformatet var inspireret af Gilly Salmons femfasemodel, der fremhæver vigtigheden af gradueret progression i læringsaktiviteter for at kunne skabe et dynamisk, virtuelt læringsmiljø, som understøtter kollaborativ læring (Salmon, 2013).

Som Salmons fremhæver, skal fokus for læringsaktiviteter på de to første trin i femfasemodellen være på, hvordan de studerende får adgang til det virtuelle læringsmiljø, og skabelsen af et miljø, hvor de oplever at være en 
del af et praksisfællesskab (Salmon, 2013). Derfor blev de studerende både mundtligt og skriftligt introduceret til blogs med fokus på formål, format og det tekniske. Som det anbefales af Williams (Williams 2002) blev formålet med blogging tydeliggjort og forventningsafstemt, således at det blev klart for de studerende, hvorfor de skulle skrive blogindlæg. Den mundtlige introduktion foregik på klassen, hvor der var mulighed for at stille spørgsmål. For at imødekomme Salmons råd om at byde de studerende velkommen online (Salmon, 2013), udarbejdede underviser det første blogindlæg, som bød de studerende velkommen, og med link til en vejledning, som de studerende kunne tilgå ved vanskeligheder.

På det tredje trin skal de studerende opleve, at det er nemt at få adgang til information fra deres medstuderende(Salmon, 2013), og her skal underviseren sørge for at designe aktiviteter, der stimulerer de studerende til aktivitet. Derfor fik de studerende konkrete opgaver at løse, således at de blev stimuleret til aktivitet på bloggen. På trin fire og fem skal de studerende være i stand til at arbejde kollaborativt og skabe viden sammen, og det er her, at der er fokus på skabelse af viden og udvikling.

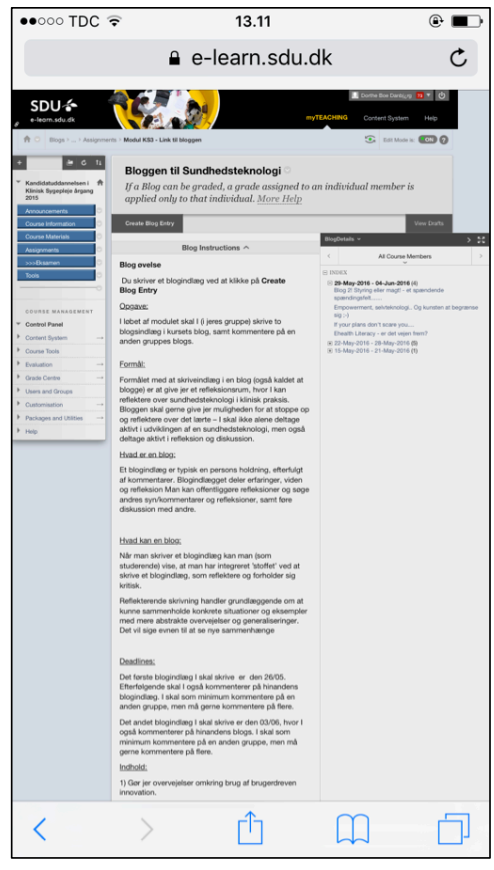

Billede 1

Salmon og Williams påpeger, at der ikke automatisk sker en interaktion ved blogging (Salmon, 2013; Williams \& Jacobs, 2004). Derfor skulle de studerende udover de faste opgaver med at skrive blogindlæg også kommentere på hinandens indlæg på lige fod med underviserne.

Blogaktiviteten var planlagt som en integreret del af modulet. Der blev afsat to undervisningsdage, og der blev afsat tid i undervisningen til 
opfølgning på deres blogindlæg for at integrere det med tilstedeværelsesundervisningen.

\section{Deltagere}

Alle 24 studerende på modulet deltog i interventionen, ligesom de alle blev inviteret til at deltage i en fokusgruppe. De studerende blev inviteret mundtligt på klassen, skriftligt på Blackboard (SDU's e-læringsplatform) samt på en facebookgruppe, der var oprettet i forbindelse med modulet. I alt fem studerende havde mulighed for at deltage i fokusgruppen, tabel 1.

\begin{tabular}{|c|c|c|}
\hline Deltagere & Alder & $\begin{array}{l}\text { Uddannet som } \\
\text { sygeplejerske - } \\
\text { angivet i år }\end{array}$ \\
\hline Maria & 33 & 8 \\
\hline Kamilla & 29 & 6 \\
\hline Else & 32 & $11 / 2$ \\
\hline Kristoffer & 39 & 16 \\
\hline Mie & 28 & $11 / 2$ \\
\hline
\end{tabular}

Tabel 1 Oversigt over karakteristika over deltagerne i fokusgruppen

\section{Dataindsamling}

Dataindsamling - blogs

Data fra bloggen blev indsamlet via Blackboard. Blogindlæggene og kommentarerne blev printet fra Blackboard.

Datagenerering - fokusgruppeinterview

De kvalitative data blev genereret gennem en fokusgruppe ledet af en moderator (førsteforfatteren) og en medmoderator, som var en underviser fra modulet.

Fokusgruppeinterview blev valgt, fordi det er kendetegnet ved dialog og diskussion (Barbour, 2007). Hermed kan det mobilisere associationer deltagerne imellem og dynamikken i gruppen kan skabe nye nuancer og perspektiver på de studerendes oplevelser med at blogge.

Fokusgruppen blev overordnet styret af en interviewguide, inspireret af tragtmodellen (Halkier, 2008, 2010). Tragtmodellen er en kombination af to typer fokusgruppeinterviews: en løs, deltagerstyret og en moderatorstyret. Derfor startede fokusgruppegruppeinterviewet med åbne spørgsmål (tragtens brede del) efterfulgt af mere fokuserede spørgsmål (tragtens smalle del). 
Den første del af interviewguiden indeholdt således åbne spørgsmål, og var kun styrende i form af strukturering af de overordnede temaer til diskussion. Temaerne i interviewguiden var; umiddelbarheder ift. gode oplevelser af undervisningen, hvad de studerende manglede samt diskussion af det at blogge. Her blev der anvendt en skriveøvelse for at give de studerende mulighed for kort selv at reflektere inden diskussionen gik i gang (Stewart \& Shamdasani, 2014).

Til slut blev fokusgruppeinterviewet mere fokuseret ved, at de studerende blev præsenteret for prompts (Albrechtsen, 2017) i form af kort, som indeholdt statements inspireret af litteratur om praksisfællesskaber og om blog som læringsaktivitet (Farmer et al., 2008; Osman \& Koh, 2013; Wenger, 2004). Se billede 2 for eksempel. Kortene indeholdt ord som engagement, fælles sprog, dialog etc. Prompts blev anvendt som kreativt middel til at fokusere og stimulere samtalen i forhold til forskningsspørgsmålet om refleksion og praksisfællesskab. Prompts kan netop fokusere samtalen i forhold til det specifikke, som der undersøges og gøre samtalen mellem de studerende mere konkret i relation til emnet, som $ø$ nskes belyst (Albrechtsen, 2017). Fokusgruppen blev optaget som lydfil og efterfølgende transskriberet. Fokusgruppen varede halvanden time.

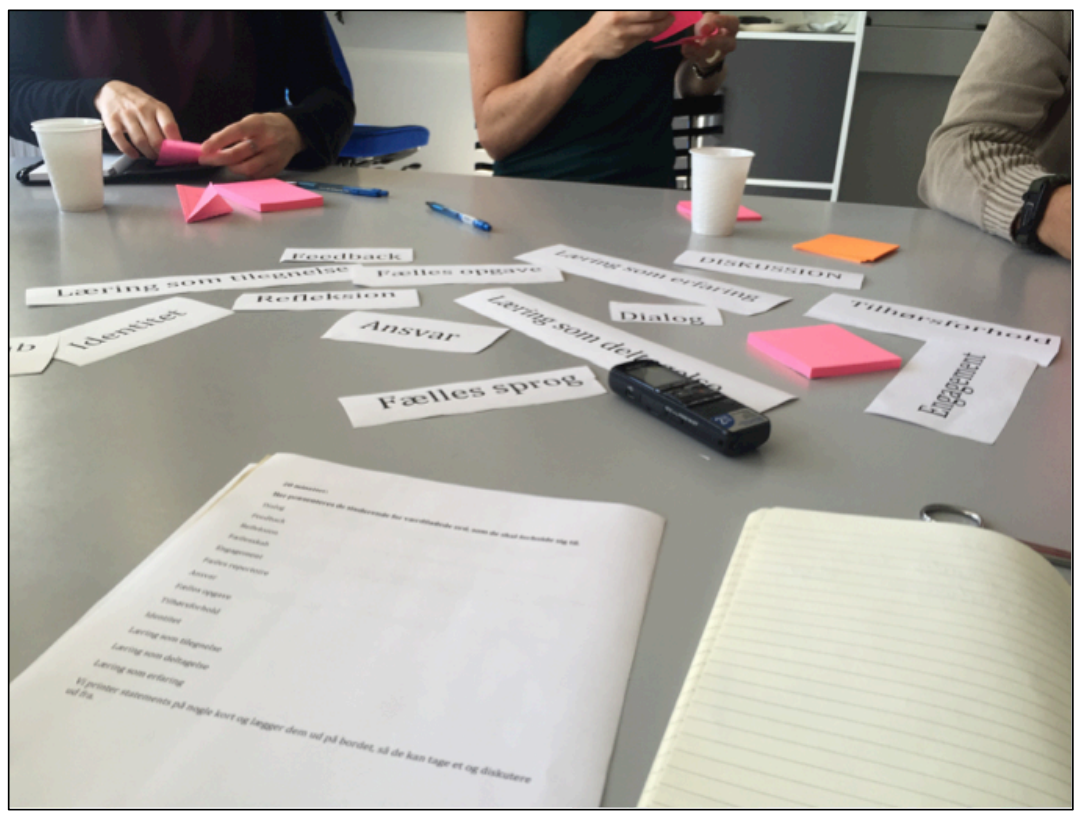

Billede 2

\section{Analyse og resultater}

\section{Analyse af blogindlæg}

Der var i alt ni blogindlæg, da én gruppe ikke skrev blogindlæg nummer to. Blogindlæggene var mellem 200-400 ord. De var alle på nær et lavet $\mathrm{i}$ Word, og efterfølgende uploadet som vedhæftet fil på bloggen, fordi de 
studerende havde haft svært ved at skrive direkte i funktionen på Blackboard. Syv ud af ni blogindlæg var udover tekst suppleret med billeder, symboler og fremhævet tekst (Billede 3).

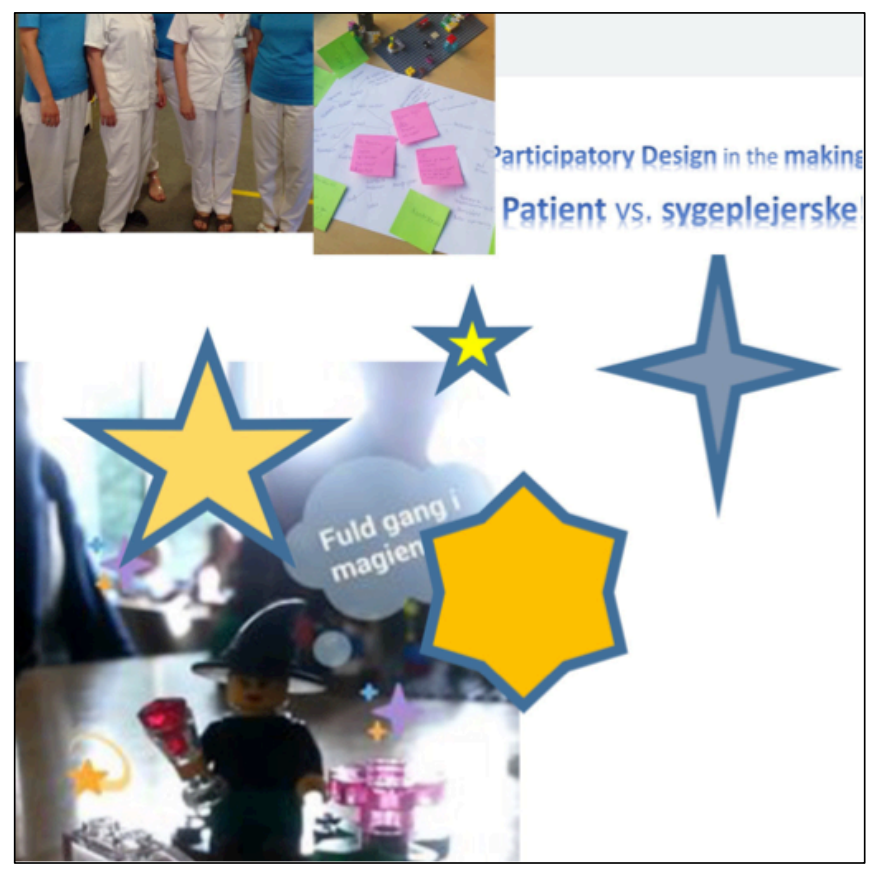

Billede 3

Det anvendte kodeskema tager udgangspunkt i Kember et.al's skema (Kember d., 2008). Hver kategori blev suppleret med Blooms taksonomier (Mørcke AM., 2013) for at uddybe de enkelte kategorier.

Al tekst blev inddelt i enheder vha. kategorierne i skemaet. Alle enheder blev kodet med undtagelse af enkelte passager som fx var introducerende eller afsluttende tekst. Førsteforfatteren havde forud for kodning sat sig grundigt ind i kodningsprocessen. Herefter blev kodeskemaet printet og lagt på bordet ved siden af teksten, som skulle kodes. Teksten blev gennemlæst og herefter vurderet i forhold til de enkelte koder. Hvis teksten fx blev vurderet til at være refererende, så blev den kodet med grøn, som var farven på non refleksion (se billede 2). Som Kember fremhæver, kan der være enkelte passager, der placerer sig mellem to kategorier og derfor ikke passer ind i skemaet (Kember d., 2008). Ved tvivlstilfælde blev passagerne genlæst, og de blev placeret i den laveste af de to kategorier. Det er alene teksten, som er kodet. De supplerende billeder eller symboler er ikke medtaget i kodningen.

Efterfølgende blev kommentarerne til de enkelte blogindlæg kodet ud fra samme fremgangsmåde 
Non refleksion (grøn)

Non refleksion er kendetegnet ved, at den studerende skriver noget uden at forholde sig til det. Den studerende skriver fx om noget, som hun har gjort, men der er ingen

kommentarer eller meta tekst, som viser, at den studerende har tænkt over handlingen eller det hun skriver.

Den studerende viser, at hun kan beskrive, redegere for eller gengive enten teori eller praksis.

På BT viser den studerende udelukkende, at hun har kendskab til noget.

Forståelse (rød)

Forstående skrivning er kendetegnet ved, at den studerende seger at forstå et begreb eller et emne. Den studerende kobler dog ikke erfaringer og praksis med teori. Teori kan godt anvendes, men det er ikke relateret til praksis. Den studerende kan godt være reflekteret, men det er uden brug af teori.

På BT viser den studerende, at hun har forståelse for praksis, kan fortolke og med egne ord beskrive situationer.

Refleksion (gul)

Her viser den studerende, at hun kan bruge teori og begreber. Hun forholder sig til det $\mathrm{i}$ relation til praksis og eller egne erfaringer. Teori bliver anvendt til at belyse og perspektivere. Den studerende viser en personlig indsigt, som går ud over teori.

På BT viser den studerende, at hun kan anvende, analysere og lave en syntese

karakteriseret ved, at hun afprøver og søger at frembringe ny viden. Der kan være vurdering kendetegnet ved diskussion. Men det som adskiller denne kategori fra kritisk refleksion er, at der ikke er et forandret perspektiv som følge af refleksionen.

\section{Kritisk Refleksion (lyserød)}

Det er det højeste niveau af refleksion, det som adskiller dette niveau fra niveauet

'refleksion' er, at den studerende her viser, at hun gennemgår en forandring. Hendes perspektiv ændrer sig som konsekvens af refleksion.

På BT viser den studerende, at hun kan analysere, lave syntese og en vurdering. Hun er kritisk og diskuterende.

Tabel 2 Kodeskema (BT = Blooms Taksonomi)

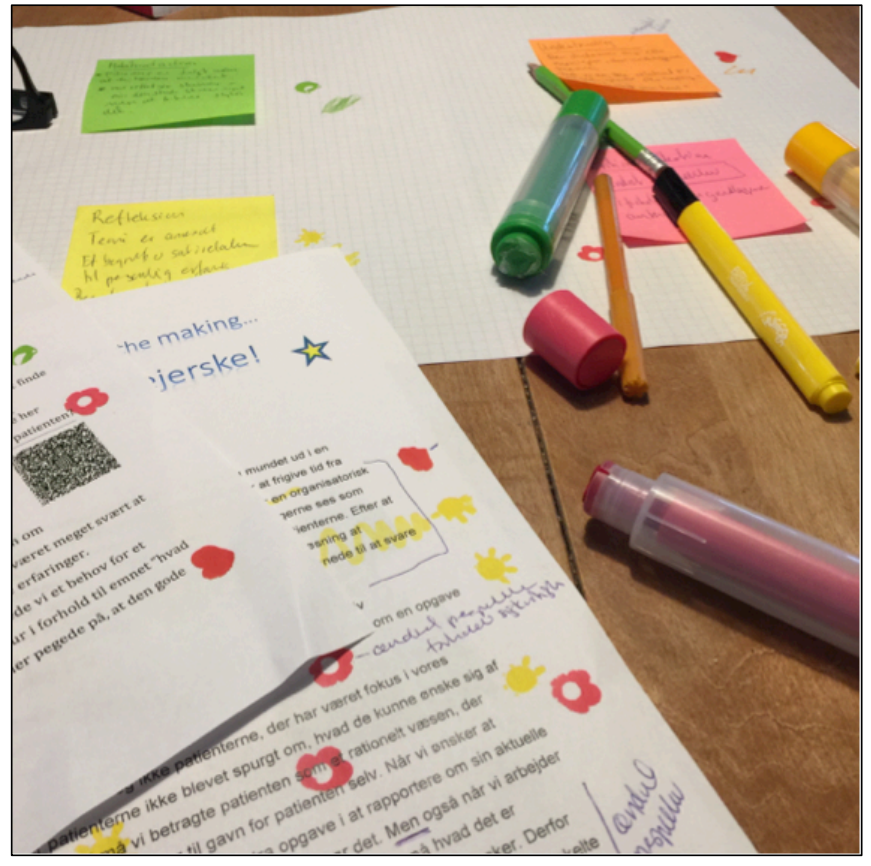

Billede 4 


\section{Resultater - blogindlæg}

De ni blogindlæg blev inddelt i 37 enheder og tildelt en kode. Atten ud af 37 tekstbidder var kodet som refleksion eller kritisk refleksion. Dvs. at cirka halvdelen af teksterne havde tegn på refleksion. Nedenstående viser et eksempel på refleksion, hvor teorien sættes i spil med de studerendes overvejelser om deres arbejde med den kliniske problemstilling.

'Jævnfør Kant må vi betragte patienten som et rationelt væsen, der alene er $i$ stand til at vurdere, hvad der er til gavn for patienten selv. Når vi ønsker at indføre en teknologi der påfører patienten en ekstra opgave i at rapportere om sin aktuelle tilstand, skal vi tænke på hvad vi beder om, og hvorfor vi gør det'.

Det følgende blogindlæg er kodet som kritisk refleksion, idet de studerende viser, at de har ændret perspektiv - de har flyttet sig fra en forforståelse af, at teknologi gør noget af sig selv, til et syn på teknologi, som noget der medierer.

'Vi er efterhånden blevet klogere på, at teknologi ikke gør noget af sig selv, men sammenkæder menneskers praksis og organiseringen heraf. Den teknologiske tavle vi påtænker til afdelingen skal mediere med personalet. Mediering skal ses som at forbinde og formidle'.

Tolv ud af 37 af tekstbidderne var kodet som forståelse, hvor der også var tegn på refleksion, men dog uden at teori var bragt i spil.

Syv ud af 37 blev kodet som non refleksion. Nedenstående viser et eksempel på hvordan de studerende udelukkende refererer til hvad de har gjort, uden at forholde sig til det eller uddybe overvejelser omkring fx valg af metode til datagenerering.

'Vores første ide opstod, efter udlevering af en case, ved søgning af baggrundsviden om den afdeling, problemstillingen forekommer i. Ved gatekeepermøde blev problemstillingen yderligere uddybet, og feltobservation og uformelle samtaler valgt som metode til datagenerering'

\section{Kommentarer til blogindlæg}

Der var i alt 33 kommentarer. Seksten fra medstuderende og 17 fra undervisere. Alle blogindlæg fik som minimum to kommentarer. To af kommentarerne blev kodet som non refleksion, dvs. de forholdt sig kun refererende eller konstaterende og åbnede ikke op for yderligere refleksion. Fire af dem var forstående. 22 af kommentarerne stimulerede til yderligere refleksion ved brug af begreber og eller teorier, som nedenstående er et eksempel på. 
Hej :-)Rigtig fint blog-indlæg! Vi fornemmer, at I også har mange tanker og begreber i spil - ligesom vi har :-) Det er spændende, men også en - til tider lidt frustrerende proces ;-)Magt-begrebet er spændende at fá belyst i jeres situation. Skal man gå med sin idé og 'prikke' lidt til afdelingens eksisterende holdninger? Eller skal man blot holde sig til deres ønsker - velvidende, at de måske ikke kender mulighederne? God weekend

Kendetegnende for de forstående og reflekterende kommentarer var, at de stimulerede til yderligere refleksion, hvor det der adskilte dem var brugen af teori. Fem kommentarer fokuserede på tekniske udfordringer.

\section{Analyse af fokusgruppeinterview}

Data er analyseret med inspiration fra Kvales meningskondenserende metode (Kvale \& Brinkmann, 2015) og Malteruds systematiske tekstkondensering (Malterud, 2011). Analysen har været henholdsvis dataog teoristyret (Malterud, 2011). Undersøgelsens teoretiske ramme dannede en overordnet ramme for analysen. Materialet fra fokusgruppeinterviewet blev anvendt til at svare på spørgsmålet om, hvordan de studerende oplever at blogge i forhold til at understøtte mulighed for refleksion i et læringsfællesskab. Først blev det transskriberede interview læst igennem for at skabe et overblik over materialet samt udlede umiddelbare temaer om de studerendes oplevelse af at blogge. Temaerne repræsenterede et første intuitivt databaseret trin i analysen af materialet, og dannede fundamentet for den yderligere analyse. Herefter blev det transskriberede materiale gennemgået for at identificere meningsbærende enheder, hvilket indebar at gennemlæse materialet linje for linje og at markerer enheder. Den teoretiske ramme var styrende for analysen, hvor de dele af teksten blev medtaget i den videre analyse, som udsagde noget om selve undersøgelsesspørgsmålet om hvordan de studerende oplevede det at blogge.

Efterfølende blev de meningsbærende enheder kodet og sorteret i forhold til de temaer, som blev fundet ved den første gennemlæsning, hvorefter der fremkom én overordnet kategori og fire underkategorier (tabel 3).

Det er førsteforfatter, der har gennemført analyserne. Herefter er de diskuteret med sidste forfatter, hvorefter de er sammenskrevet og diskuteret med resten af forfattergruppen. 


\begin{tabular}{|c|c|c|c|}
\hline $\begin{array}{l}\text { Trin I: Fra vildnaes } \\
\text { til overordnede } \\
\text { temaer udledt efter } \\
\text { den forste abne } \\
\text { lessning af teksten }\end{array}$ & $\begin{array}{l}\text { Trin 2: Fra temaer til koder: Identificeri } \\
\text { meningsbarende enheder. De meningsb } \\
\text { kodede med udgangspunkt i de oprindeli } \\
\text { laringsteori }\end{array}$ & $\begin{array}{l}\text { ng af } \\
\text { erende enheder er } \\
\text { ge temaer og }\end{array}$ & $\begin{array}{l}\text { Trin 3: Fra koder til } \\
\text { mening. De menings- } \\
\text { barende enheder } \\
\text { blev sorteret i en } \\
\text { overordnede } \\
\text { kategorier og fire } \\
\text { underordnede. }\end{array}$ \\
\hline $\begin{array}{l}\text { Associationer } \\
\text { Tvunget til at skrive } \\
\text { ned }\end{array}$ & $\begin{array}{l}\text { Forst da du navnte det, taenkte jeg, } \\
\text { argh. Fordi det jeg forbinder med blogs } \\
\text { er noget inde pá de sociale medier, } \\
\text { hvor man skal lase om folk og deres } \\
\text { syge born, men sã tankte jeg, at det var } \\
\text { en god måde at bruge det pà (...) 'Jeg } \\
\text { synes egentlig, at det var godt at fá } \\
\text { noget ned pã papir' } \\
\text { 'Men det blev ogsà meget tydeligt, at } \\
\text { man kunne lare af de andre, hvorfor } \\
\text { har de skrevet sádan, hvorfor har de } \\
\text { valgt det begreb (...) ogsá at lare } \\
\text { hvordan griber de det an, der kan man } \\
\text { blive inspireret og omtanke det man } \\
\text { selv gor' }\end{array}$ & (godt at skrive) & $\begin{array}{l}\text { En god mâde at } \\
\text { reflektere sammen } \\
\text { med andre }\end{array}$ \\
\hline $\begin{array}{l}\text { Tid } \\
\text { Prioriteringer }\end{array}$ & $\begin{array}{l}\text { 'Eller ogsã kan man se fidusen, men } \\
\text { tanker, at det ikke er det som er vigtigt } \\
\text { lige nu. Fordi vi ogsã havde en opgave, } \\
\text { der skulle skrives, og en gruppe der } \\
\text { skulle modes (...) der var mange ting. } \\
\text { der spillede ind. Og pávirkede' }\end{array}$ & $\begin{array}{l}\text { (svaert at nà at } \\
\text { skrive) }\end{array}$ & $\begin{array}{l}\text { Manglende tid, } \\
\text { usikkerhed \& } \\
\text { tekniske } \\
\text { udfordringer }\end{array}$ \\
\hline
\end{tabular}

Tabel 3: Eksempel på den systematiske tekstkondensering

\section{Resultater}

Der fremkom to overordnede temaer En god måde at reflektere sammen med andre og Manglende tid, usikkerhed \& tekniske udfordringer, som udfoldes efterfølgende.

\section{En god måde at reflektere sammen med andre}

Blogging udfordrede de studerende, fordi de ikke umiddelbart forbandt det med noget, der foregår på universitetet, og fordi de fik associationer til alt anden end læring, da de først blev præsenteret for ideen.

'Først da du nævnte det, tænkte jeg, argh. Fordi det jeg forbinder med blogs er noget inde på de sociale medier, hvor man skal læse om folk og deres syge børn, men så tænkte jeg, at det var en god måde at bruge det på (...)'Jeg synes egentlig, at det var godt at få noget ned på papir' Kamilla

Men som ovenstående citat viser, så fik de studerende positive erfaringer med at skrive blogindlæg. En af pointerne var, at de blev 'tvunget' til at skrive. Så trods modstand til en start, så syntes de studerende i sidste ende, 
at blogs var brugbart som en måde at skrive og reflektere, selvom det var en anderledes måde at skrive på.

'Da jeg så havde skrevet det, kan jeg huske, at jeg tænkte, at det egentlig var meget sjovt at prøve at skrive noget, der var lidt anderledes og lidt mere løst, men lige da jeg skulle i gang der tænkte jeg, at det var BIP irriterende' Mie

Som en del af opgaven, skulle de studerende også kommentere på det, som de andre grupper havde skrevet. De studerende fremhævede, at det havde været inspirerende at læse de andres indlæg, og det havde bidraget til deres egen læring.

'Men også det hvis man læste en andens gruppes begreb og de havde brugt et andet begreb, så tænkte jeg: nå men hvorfor har de mon gjort det, altså det var da en form for refleksion' (mille)

De studerende oplevede, at de på den måde lærte af deres medstuderende, og de kunne bruge deres indlæg og kommentarer til at reflektere over deres egen læring.

'Men det blev også meget tydeligt, at man kunne lære af de andre, hvorfor har de skrevet sådan, hvorfor har de valgt det begreb (...) også at lære hvordan griber de det an, der kan man blive inspireret og omtænke det man selv gør' Else.

På den måde oplevede de studerende, at blogmediet åbnede op for, at de blev deltagende i hinandens læring, og at det stimulerede til, at de var aktivt engageret $\mathrm{i}$ andres læring, og samtidig bidrog deltagelsen til deres egen læring.

'Jeg synes også, at læring som deltagelse er meget sigende - hvad er en blog, det er, at man deltager og det man kunne lære noget af det var at læse de andres indlæg og være aktive' Kristoffer.

Samtidig fremhævede de studerende, at blogmediet gav en platform for fællesskab, fordi det åbnede op for, at de kunne følge hinandens læring og dermed ikke kun oplevede et fællesskab med dem de var i gruppe med.

'Fællesskab (...) inden på bloggen fik man et indblik $i$, hvad de andre lavede. Det var der, man kunne få et indblik $i$, at der også var nogle andre, som sad med det samme, ellers var man meget fordybet i sit eget. Og det gav et fællesskab, så kunne man også spørge nogle af de andre, for ellers blev det meget fokuseret på dem som man var i gruppe med. Ja lige det ord kan godt dække for noget' Mie.

De studerende var enige om, at de havde et ansvar overfor hinanden i fællesskabet, og de skulle løse de opgaver, som de blev stillet. 
'Jeg tænker meget over det med ansvar, at man har et ansvar overfor de andre i gruppen, at man tager den opgave seriøst og fär det gjort, og at vi fär snakket om det. Vi har et ansvar overfor hinanden som studerende' Kamilla.

\section{Manglende tid, usikkerhed \& tekniske udfordringer}

De studerende havde følt sig pressede undervejs i modulet, hvilket betød, at de ikke havde prioriteret at arbejde meget grundigt med blogindlæggene. De følte, at blogindlæggene blev en 'skal' opgave, som de ikke ville bruge for lang tid på, fordi de havde fokus rettet mod deres eksamensopgave.

'Ja der var den model, men det var sådan lidt, åh nej, så skulle vi også forholde os til den, og så blev det lidt mere omstændeligt, end vi nok havde lyst til at det skulle blive'. Kamilla.

Samtidig tilkendegav de studerende, at hvis de havde brugt mere tid på blogindlæggene, ville de have fået noget mere ud af det. Deres fravalg hang blandt andet sammen med, at de havde svært ved at se formålet

'Det kan godt være at vi skulle have prioriteret det lidt mere, for at det havde givet det noget mere (...). 'Ja når man kom ud på den anden side, så kunne man godt se det, men når man var i det, så ja det er godt med jer'Mie.

Nedenstående citater er et uddrag af en dialog blandt deltagerne i fokusgruppen som eksemplificerer, at de ikke havde styr på retningslinjerne for arbejdet med bloggen.

'Var der egentlig nogle regelsæt for at vi skulle skrive det sammen?' Mie

'Der var jo lagt sådan en model op så man kunne se hvordan man skulle gøre' Kamilla

'Ja, jeg ved ikke om det var meningen' Mie

'Jeg kan ikke huske det' Kristoffer.

De udtrykte flere gange tvivl om, hvordan blogindlæggene skulle skrives. De var usikre på formatet og kravene. Derudover fortalte de om tekniske udfordringer i forbindelse med at skrive deres blogindlæg. En af studiegrupperne havde forsøgt sig med video, som de andre ikke kunne afspille fra Blackboard, og andre endte med at uploade et worddokument. De ville have foretrukket, at det havde været på et mere 'autentisk' format a la wordpress.

\section{Diskussion}

\section{Resultatdiskussion}

De studerende har oplevet, at det at blogge har været givende i forhold til at understøtte et fælleskab, hvor de dels selv skulle skrive, men samtidig 
haft mulighed for at lære af hinanden hvilket har stimuleret til refleksion. Det har samtidig vist sig udfordrende i forhold til, hvordan læringsaktiviteten blev opfattet af de studerende, samt hvor pressede de studerende har følt sig undervejs i modulet.

Resultaterne viste, at over halvdelen af tekstbidderne fra blogindlæggene var reflekterende. Dette understøttes af flere studier som har vist, at brugen af blogs stimulerer til refleksion (Halic et al., 2010; Osman \& Koh, 2013; Williams \& Jacobs, 2004). Fx konkluderer Osman og Koh, at blogs har potentiale som et redskab for refleksion, idet deltagerne i deres studie demonstrerede et forholdsvist højt niveau af kritisk tænkning og de koblede teori med deres erfaringer og observationer fra praksis (Osman \& Koh, 2013).

Resultaterne viste, at kun få af tekstbidderne var non reflekterende. Imidlertid var der en stor gruppe (12 ud af 37), som ikke formåede at anvende teori i samspil med refleksionerne. Der forekommer refleksion, idet de studerende forholder sig til det, de skriver, men de formår ikke at opnå et videnskabeligt niveau, idet de ikke formår at anvende teorien (Dewey, 1933/2009). Det kan måske tilskrives uklarheden omkring formatet 'at blogge'. De studerende oplevede det som udfordrende at skulle skrive indlæggene, idet de ikke forbandt det med akademisk skrivning. Williams \& Jacobs, kunne udbyttet af at blogge have været bedre, hvis de studerende i vores studie i højere grad havde fået tydeliggjort formålet med blogging (Williams \& Jacobs, 2004). Usikkerheden omkring blogmediet understreger vigtigheden af, at der burde have været sat mere tid af til de indledende introducerende aktiviteter, dvs. de 2 første faser i femfasemodellen (Salmon, 2013), hvor formålet med øvelsen skulle have været tydeligere. Ligeledes retter det opmærksomheden mod, at selvom de studerende er vant til at være online og på de sociale medier, så kan de alligevel blive usikre, når de skal træde ind i rollen som online studerende (Christensen, 2016). Dette underbygges også af Farmers studie, hvor flere af de studerende efterlyste mere detaljerede guidelines i forhold til at blogge. Han fandt, at selvom de studerende var fortrolige med blogs, så forbandt de ikke blogging med en reflekterende praksis (Farmer et al., 2008). Ligeledes fyldte tekniske udfordringer i vores undersøgelse uhensigtsmæssigt meget, hvilket kan have været hæmmende for de studerendes engagement i opgaven, og vi har tilsyneladende ikke formået at introducere de studerende kvalificeret til det virtuelle læringsmiljø (Salmon, 2013). Dette understøttes igen af Farmers undersøgelse, hvor de studerende efterlyser mere information om, hvordan det tekniske håndteres (Farmer et al., 2008). Fortroligheden med blogs som akademisk skrivning vil nok kunne styrkes ved, at blogformatet bliver mere bredt anvendt på hele studiet. 
De studerende i aktuelle studie tilkendegav, at den skepsis, de havde indledningsvist ved at skulle skrive blogindlæg, blev erstattet af, at de kunne se potentialet i aktiviteten. De studerende fremhævede at få noget ned på papir gav dem mulighed for refleksion. Det er kendt, at skriftlighed understøtter refleksion, eftersom tanken skabes gennem sproget, og det giver mulighed for fordybelse ((Dysthe, 2001; Ulstrup \& Haugaard Jeppesen, 2010). Derudover understøttede brugen af blogs, at de studerende lærte af hinanden. De studerende oplevede, at deres medstuderendes input og indlæg var inspirerende, og det medvirkede til, at de retænkte det, de selv havde gjort, hvilket øgede deres refleksionsniveau. Det kan ses som et brud på vanetænkning og er netop kendetegnende for en reflekterende praksis (Osman \& Koh, 2013; Schön, 1991), hvilket er karakteristisk for et kritisk refleksionsniveau (Kember d., 2008). Dette bekræfter det dynamiske potentiale ved blogs. Farmer fremhæver, at blogs netop på grund af den egenskab bliver karakteriseret som en form for monolog og dialog, hvor de studerende gennem den online skriftlighed både kan udtrykke deres egne ideer, men samtidig engagerer sig $\mathrm{i}$ interaktiv kontakt med andre, som kan fremme deres refleksion (Farmer et al., 2008).

Ulstrup og Haugaard Jeppesen argumenterer for, at det at skrive kan skabe et fagligt fællesskab, og det kan være et af forskellige dialogiske læringsrum, der er indenfor akademisk praksis. Netop dette understøtter vores undersøgelse, idet de studerendes oplevelser kan ses som et udtryk for, at bloggen har styrket deres oplevelse af at være i et forpligtende læringsfællesskab.

I forhold til Lave og Wengers teori om praksisfællesskab forudsætter det at blive fuldgyldigt medlem af praksisfællesskabet aktiv deltagelse og hermed anvendelse af praksisfællesskabets teknologier, deltagelse i de sociale relationer etc. (Lave \& Wenger, 2003). Resultaterne viste, at blogmediet styrkede fælleskabet, idet de studerende fik mulighed for at deltage i hinandens læring, lære af hinandens refleksioner og hermed engagere sig $\mathrm{i}$ hinanden. Ifølge Wenger er deltagelse en kompleks størrelse; det er ikke noget, der tændes og slukkes for. Det vil sige, at deltagelse rækker videre end et direkte engagement $\mathrm{i}$ bestemte aktiviteter sammen med bestemte mennesker. Deltagelse udgør det, som Wenger kalder en konstituerende del af vores identitet (Wenger, 2004). Blogging har optrådt som en konkret aktivitet, og har fungeret som en transformational technologie og hermed styrket læringsfællesskabet udenfor klasserummet (Williams \& Jacobs, 2004) og hermed understøttet de studerendes deltagelse i et interaktivt praksisfællesskab (Farmer et al., 2008).

\section{Metodediskussion}


Det kan diskuteres om samme resultater kunne været nået ved andre online platforme som wikis, eller diskussionsfora. De tre værktøjer har flere ligheder, men alligevel er formatet ikke helt ens. En blog kan sammenlignes med en online dagbog, hvor en studerende (eller en gruppe) poster for herefter at læserne kommentere, er wiki mere en måde sammen at skabe et indhold, hvor den enkeltes refleksion ikke kommer så meget i spil som på blogmediet (Teaching at UNSW Sydney). Ligesom en wiki repræsenterer konsensus, hvor et blog post er et udtrykt for den enkeltes refleksion

Diskussionsforum har flere ligheder med bloggen, hvor de studerende kan starte en ny diskussion eller svare på eksisterende, dog er blogmediet mere personligt, da en blog er 'ejet' af et individ eller en gruppe.

Tilgangen med anvendelse af forskellige metoder og data har givet nuancerede resultater vedrørende blogging. De empiriske data fra fokusgruppen kan være påvirket af moderatorernes rolle i forhold til de studerendes ærlighed, fordi moderatorerne havde en dobbeltrolle i og med at de var undervisere på modulet. Dette imødekom vi ved at gennemføre fokusgruppen efter eksamen. Det syntes som en styrke, at moderatorerne på forhånd kendte de studerende, idet de studerende fra start til slut $\mathrm{i}$ interviewet var engagerede og fremstod ærlige.

Derudover kan der stilles spørgsmål i forhold til validiteten og reliabiliteten i undersøgelsen. Vi undersøger egen undervisningspraksis, hvorfor det er vigtigt at fremhæve, at validitet og reliabilitet også afhænger af forskerens evne til blandt andet at være refleksive omkring processen. Vi var flere forskere tilknyttet projektet, og brugte hinanden til at diskutere data og resultaterne undervejs i processen.

I forhold til om resultaterne lader sig overføre vil vi referere til Brinkmann, som bruger begrebet analytisk generaliserbarhed som opstår i en dialektik mellem teori og praksis. De empirisk generede data blev diskuteret og bragt i dialog med teori og relevante studier (Brinkmann, 2014).

Vi valgte at anvende et allerede valideret kodeskema (Bell et al., 2011; Kember d., 2008). Dog valgte vi at supplere skemaet med Bloom's taksonomier. Vi vurderer, at det ikke har afgørende betydning i forhold til, hvorvidt skemaet har mistet validitet, idet vi ikke har lavet om i kategorierne, blot suppleret med yderligere nuancer, så det blev målrettet indeværende undersøgelse.

\section{Konklusion}

Undersøgelsen havde til hensigt at afdække, hvordan studerende oplever at blogge i forhold til at understøtte mulighed for refleksion i et læringsfællesskab samt hvilke niveauer for refleksion der understøttes. 
De studerende oplevede, at blogmediet tilbyder en platform, som kan styrke deres læringsfælleskab, hvor de får mulighed for at engagere sig i hinandens læring. Hermed kan det konkluderes, at blogmediet kan understøtte studerendes deltagelse i et interaktivt praksisfællesskab, hvor der er rum til refleksion.

Det kan desuden konkluderes, at muligheden for refleksion forringes ved uklarhed over opgaven og ved usikkerhed på hvordan blogmediet bruges. Anvendelse af blogs udfordrer de gængse opfattelser af læring og læringsaktiviteter. Det kan derfor konkluderes, at introduktion til blogmediet bør være grundig, for at de studerende er trygge ved at være onlinestuderende.

Det kan yderlige konkluderes, at anvendelse af blogs stimulerer til refleksion, idet der var tegn på refleksion i størstedelen af de studerende blogindlæg, men det skal også fremhæves, at 1/3 af indlæggene ikke formåede at koble teorien til refleksioner over praksis, og dermed ikke når et videnskabeligt reflekterende niveau.

\section{Tak}

En særlig tak til de studerende - både for at være med på at prøve noget nyt, og ikke mindst for at dele jeres oplevelser med os.

\section{Referencer}

Bell, Amani, Kelton, Jill, McDonagh, Nadia, Mladenovic, Rosina, \& Morrison, Kellie. (2011). A critical evaluation of the usefulness of a coding scheme to categorise levels of reflective thinking. Assessment \& Evaluation in Higher Education, 36(7), 797-815.

Christensen, IMF. (2016). How do you design a good study start for blended at distance learning courses?. Paper presented at the TAL Teaching for active learning Odense

Davidsen, Jacob, \& Ryberg, Thomas. (2016). Samhørighed, interaktion og vidensdeling blandt studerende-erfaringer fra et IKT-pædagogisk udviklingsprojekt. Dansk Universitetspædagogisk Tidsskrift, 11(21), 57-71.

Dewey, J. (1933/2009). Hvordan tænker vi - en reformulering af forholdet mellem refleksiv tænkning og uddannelsesprocessen: Klim

Dysthe, Olga. (2001). The mutual challenge of writing research and the teaching of writing. Paper presented at the Investigación presentada en la primera conferencia de la European Writing Centre Association. University of Groeningen, Nederland. Recuperado de http://www. uib. no/plf/ansatte/olga/keynote.

Dysthe, Olga. (2002). The learning potential of a web-mediated discussion in a university course. Studies in Higher Education, 27(3), 339-352.

Farmer, Brett, Yue, Audrey, \& Brooks, Claire. (2008). Using blogging for higher order learning in large cohort university teaching: A case study. Australasian Journal of Educational Technology, 24(2), 123136. 
Halic, Olivia, Lee, Debra, Paulus, Trena, \& Spence, Marsha. (2010). To blog or not to blog: Student perceptions of blog effectiveness for learning in a college-level course. The Internet and higher education, 13(4), 206-213.

Halkier, Bente. (2010). Fokusgrupper: Den fokuserede socialitet Kvalitative Metoder (pp. 121-135): Hans Reitzel.

Kember d., McKay J., Sinclair K., Frances KYW., . (2008). A four-category scheme for coding and assesing the level of reflection in written work. Assesment \& Evaluation in Higher Education 33(4), 13.

Lave, Jean, \& Wenger, Etienne. (2003). Situeret læring - og andre tekster. Kbh.: Hans Reitzel.

Osman, Gihan, \& Koh, Joyce Hwee Ling. (2013). Understanding management students' reflective practice through blogging. The Internet and Higher Education, 16, 23-31.

Papacharissi, Zizi. (2007). Audiences as media producers: Content analysis of 260 blogs. Blogging, citizenship, and the future of media, 21-38.

Salmon, G. (2013). E-tivities -The key to active online learning. (Vol. Second Edition ): Routledge.

Schön, Donald A. (1991). The reflective practitioner : how professionals think in action (11th repr. ed.). Aldershot: Avebury Ashgate.

Sim, Jeffrey Wee Sing, \& Hew, Khe Foon. (2010). The use of weblogs in higher education settings: A review of empirical research. Educational Research Review, 5(2), 151-163.

Ulstrup, Eva, \& Haugaard Jeppesen, Mai-Britt. (2010). Dialogiske læringsrum med plads til hjerne og hjerte. Dansk universitetspædagogisk tidsskrift, 5(9), 59-62.

Wenger, Etienne. (2004). Praksisfællesskaber : læring, mening og identitet. Kbh.: Hans Reitzel.

Williams, Jeremy B, \& Jacobs, Joanne S. (2004). Exploring the use of blogs as learning spaces in the higher education sector. Australasian journal of educational technology, 20(2), 232-247.

Wrede, Oliver. (2003). Weblogs and discourse: Weblogs as a transformational technology for higher education and academic research. Paper presented at the Blogtalk Conference Paper, Vienna, May 23rd-24th. 